\title{
Antidepressant-like effects and mechanisms of flavonoids and related analogues
}

\author{
Li-Ping Guan*, Bing-Yu Liu
}

Food and Pharmacy College, Zhejiang Ocean University and Zhejiang Provincial Engineering Technology Research Center of Marine Biomedical Products, Zhejiang, Zhoushan 316022, P. R. China.

*Address correspondence to this author at the Food and Pharmacy College, Zhejiang Ocean University, Zhoushan City, Zhejiang Province, 316022, P. R. China. Tel: +86-580-2555280; Fax: +86-580-2554781. E-mail: glp730@163.com. 


\section{ABSTRACT}

Flavonoids, possessing a basic phenylbenzopyrone core, are important components of the human diet, and are found in many medicinal plants. Flavonoids include chalcones, flavanones and their derivatives. Synthetic and natural isolated flavonoids display an enormous number of biological activities such as antitumor, antiplatelet, anti-malarial, anti-inflammatory, antidepressant and anticonvulsant properties. This review article focuses on the antidepressant-like effect, structure-activity relationship and mechanism of action of total flavonoid extracts isolation from natural sources, flavonoid compounds and their related analogues.

Keywords: Flavonoids, Chalcones, Flavanones, Antidepressant-like effect, Structure-activity relationship 


\section{Introduction}

Flavonoids possess a 2-phenyl-4H-chromen-4-one skeleton, and are potentially health-promoting substances (Fig. 1). Flavonoids exist in mono-, di-, tri-, tetra- or polymeric form through C-C or C-O-C linkages. Flavonoids containing two or more units are ubiquitous natural products with wide physiological activities, low toxicity and few side effects [1]. Flavonoids are phytochemicals found in a variety of fruits and vegetables and confer color, flavor, and aroma, as well as nutritional and health benefits [2-4]. Many flavonoids possess antioxidant, anti-inflammatory and antidepressant activity in animal studies [5-11].

Two subclasses of flavonoids are the phenolic $\alpha, \beta$-unsaturated ketones chalcones, which contain a 1,3-diphenyl-2-en-1-one core, and flavanones, containing a 2-phenyl-2,3-dihydro- $4 \mathrm{H}$-chromen-4-one core (Fig. 1). A large number of naturally occurring and structurally modified flavonoids, chalcones, and flavanones have been chemically synthesized, with numerous publication highlighting the synthesis and medicinal significance of these compounds [12-16]. The antidepressant effects of flavonoids, chalcones, and flavanones have caused widespread interest and have been widely studied [17-24]. This paper is a mini-review of the antidepressant-like activity of natural and synthetic flavonoid, chalcone and flavanone compounds that have been published in the last fifteen years (2000-2015). The structure-activity relationship (SAR) and mechanism of action of these compounds are also discussed.

\section{Structure-activity relationship and antidepressant effects}

Depression is one of the most prevalent psychiatric disorders, and is characterized by a decrease in an individual's ability to experience pleasure. Symptoms of depression include lowered pleasure, mood and interest. Depression is a chronic and disabling mental illness that causes high morbidity and mortality [25-27]. The World Health Organization (WHO) estimates about 350 million people suffer from depression, and predicts that by 2020 the disorder will be the second leading cause of disability worldwide [28-30]. The main biochemical causes of depression are metabolic disorders of monoamine neurotransmitters that are involved in noradrenaline (NE), serotonin (5-HT), and dopamine (DA) signaling [31, 32]. These neurotransmitters play important roles in mediating behavioral activity induced by antidepressant drugs. Brain-derived neurotrophic factors (BNDF) and gamma-aminobutyric acid (GABA) are believed to be associated with depressive disorders [33, 34]. Monoamine oxidase (MOA) is a key enzyme that is related to the metabolism of these neurotransmitters. Reduced or elevated MOA activity has been indicated as a trait-dependent indicator of vulnerability to psychopathologies [35]. The function of the hypothalamic- 
pituitary-adrenal (HPA) axis was damaged in many depressed patients [36]. Corticotropin- releasing factor, the major physiological regulator of the HPA axis system, acts within the central nervous system (CNS) to modulate a lot of behavioral, neuroendocrine and autonomic responses to environmental stimulation [37].

Although there are many effective antidepressants available today the current armamentarium is often inadequate, with unsatisfactory results in about one third of all subjects treated $[38,39]$. The discovery of new antidepressant drugs with better efficacy and fewer side effects is necessary. The antidepressant-like effect of natural and synthetic flavonoid, chalcone, and flavanone derivatives are discussed in this section.

\subsection{Extracted flavonoids}

Many flavonoids extracted from plants have been reported to possess antidepressant-like effect in animal studies. The mechanism of the antidepressant-like effect of these flavonoids in rats is reversal of monoamine neurotransmitter attenuations by 5-HT, NE and DA and 5-Hydroxyindoleacetic acid (5-HIAA), and regulation of the gene for neurotransmitter receptor expression [40-45].

A flavonoid fraction obtained from a crude extract of Hypericum perforatum (St. John's Wort) significantly induced the immobility time in forced swimming tests (FST), and showed antidepressant-like effect in mice. The fraction was further separated using multi-layer coil counter-current chromatography (MLCCC) and high performance liquid chromatography (HPLC) and composed mainly of hyperoside, isoquercitrin, miquelianin, quercetin, the aglycones quercitrin and astilbin [46, 47]. Butterweck et al. reported that the major flavonoids (hyperoside and isoquercitrin) extracted from the leaves of Apocynum venetum $L$. (Apocynaceae) markedly shortened the immobility time of male rats at doses of 30,60, and 125 $\mathrm{mg} / \mathrm{kg}$, respectively, in a FST, suggesting a possible antidepressant-like activity. The effects were comparable to that of the tricyclic antidepressant imipramine $(20 \mathrm{mg} / \mathrm{kg})$. Neither the Apocynum extract nor imipramine produced any overt behavioral changes or motor dysfunction in the open field test (OFT) [48].

Hypericum perforatum is considered an effective alternative to the synthetic antidepressants for the treatment of mild-to-moderate depression. Calapai et al. [49] used HPLC to study neurotransmitter 5-HT, $\mathrm{NE}$ and DA contents in different brain regions (diencephalon, cortex, and brainstem) of male Sprague-Dawley rats after administration of hypericum flavonoid extracts by the FST. The Hypericum extract increased 5-HT, NE, and DA levels and reduced the immobility time with acute oral administration (per os, p.o.) $(50,250$ and $500 \mathrm{mg} / \mathrm{kg})$. The antidepressant-like effect is probably mediated by serotonergic, noradrenergic, and dopaminergic system activation. 
Dhingra et al. [50] investigated the antidepressant-like activity of an aqueous extract of Glycyrrhiza glabra L. (liquorice) using the FST and the tail suspension test (TST) in mice. The extract of G. glabra was administered for 7 successive days at doses of 75, 150, and $300 \mathrm{mg} / \mathrm{kg}$ (o.p.), respectively, in Swiss young male albino mice. The $150-\mathrm{mg} / \mathrm{kg}$ dose significantly decreased the immobility time in both the FST and TST. The liquorice extract also reversed reserpine-induced extension of the immobility period. Alpha-adrenergic blocker prazosin (alpha1-adrenoceptor antagonist) and antipsychotic sulpiride significantly attenuated the extract-induced antidepressant-like activity in the TST. $p$-Chlorophenylalanine (PCPA) (inhibitor of serotonin synthesis), an inhibitor of 5-HT biosynthesis, did not invert the antidepressant-like activity of the liquorice extract. This suggests that the antidepressant-like activity of liquorice extract may be mediated by increasing brain DA and NE, and not by increasing 5-HT.

Xiaobuxin-Tang (XBXT) is a traditional Chinese herbal decoction. Zhang et al. [51] found that the ethanolic extract of XBXT significantly decreased the immobility time in the TST and FST in mice and rats [52]. Acute and sub-chronic treatments with the total flavonoids (XBXT-2) extracted from XBXT exerted excellent antidepressant-like effect in animal depression, behavioral despair, and learned helplessness models in rats. XBXT-2 may contain the most active antidepressant components of XBXT [53]. An et al. [54] demonstrated that administration of XBXT-2 (25 and $50 \mathrm{mg} / \mathrm{kg}$, p.o.) reversed the behavioral alterations and serotonergic dysfunctions in chronic mild stress (CMS) rats, suggesting that XBXT-2 exerted significant antidepressant-like effect, and that serotonergic activation might be involved in XBXT-2 effect. An et al. further demonstrated that XBXT-2 possesses excellent antidepressant-like effect in multiple animal models of depression. Morphologic and functional regulation in the hippocampus, including up-regulation of hippocampal neurogenesis and neurotrophins expression, may be involved in its antidepressant-like efficacy of XBXT-2.

Messaoudi et al. [55] reported antidepressant-like activity of cocoa polyphenolic extract, a complex mixture prepared from non-roasted cocoa beans including high contents of flavonoids using the FST in rats. Their studies showed that cocoa polyphenolic extract significantly lessened the duration of immobility at doses of 24 and $48 \mathrm{mg} / \mathrm{kg}$ for 14 days, respectively. No change in motor dysfunction was observed with two doses in OFT. Locomotor effect tests confirmed the assumption that the antidepressant-like effect of cocoa polyphenolic extract is specific after subchronic treatment in the FST model. 
Byrsonima crassifolia (Malpighiaceae) has been used in traditional medicine to treat some mental-related diseases. Herrera-Ruiz et al. [56] reported that the methanolic extract of Byrsonima crassifolia significantly decreased the immobility time at a dose of $500 \mathrm{mg} / \mathrm{kg}$ in the FST of mice and displayed a significant antidepressant-like effect $(P<0.05)$. The main flavonoid compounds of the methanolic extract were postulated as quercetin, quercetin 3-O-xyloside, rutin, and hesperidin, which may be involved in the antidepressant-like effect. The methanolic extract standardized on the flavonoid contents could be considered relatively safe because toxicological testing resulted in no deaths of mice at a dose of $2000 \mathrm{mg} / \mathrm{kg}$ through the oral route.

The methanol extract from flowers of Hibiscus rosa-sinensis Linn (Malvaceae), popularly known as "China-rose flowers", contain flavonoids including anthocyanins (MHR) and anthocyanidins (AHR). Shewale et al. [57] evaluated the antidepressant-like effect of MHR and AHR at doses of 30 and $100 \mathrm{mg} / \mathrm{kg}$ using the FST and TST in mice. The antidepressant-like activity of these extracts were investigated by observing their effect on mice pre-treatment with low dose haloperidol (classical $\mathrm{D}(2)$-like dopamine receptor antagonist), prazosin and PCPA in the FST and TST. MHR and AHR significantly decreased the immobility time, similar to the effect of the antidepressant imipramine. Both MHR and AHR possess antidepressant-like activity, which may be regulated by noradrenergic, serotonergic, and dopaminergic system activation.

Zheng et al. [58] explored the antidepressant-like effect and mechanism of flavonoids extracted from Apocymum venetum (AV) leaves. Administration of the AV extract at intraperitoneal (i.p.) doses of 25, 50 and $100 \mu \mathrm{g} / \mathrm{mL}$ significantly lessened the immobility time and showed the antidepressant-like activity in the FST and TST in mice. The study supports the neurotransmitter hypothesis of depression. The antidepressant-like effect of the AV-extract are likely because of increasing NE and DA, along with their respective metabolites dihydroxyphenylacetic acid (DOPAC) and homovanillic acid (HVA), in treated rats and dependent on interaction with dopaminergic $\left(\mathrm{D}_{1}\right.$ and $\mathrm{D}_{2}$ receptor) systems in rat brain tissue. The AV-extract induced $\mathrm{Ca}^{2+}$ concentration and protected $\mathrm{PC} 12$ cells from the injury by incubation with corticosterone for $48 \mathrm{~h}$, indicating the mechanism of the $\mathrm{AV}$-extract might be related to neuro-protection achieved by decreasing $\mathrm{Ca}^{2+}$ concentration that promotes cell proliferation $[59,60]$.

Fan et al. [61] investigated the antidepressant-like effect and related neurogenesis protective effect of the total flavonoid (licorice flavonoids) extract of Glycyrrhiza uralensis Fisch. The antidepressant-like 
effect was elucidated by the FST, TST and OFT. 5'-Bromo-2'-deoxyuridine (BrdU) labeling experiments were used to test the neurogenesis protective activities. The rats were given the total flavonoids at three doses $(30,100$, and $300 \mathrm{mg} / \mathrm{kg}$ ) and nine unpredictable sequences of stressors were investigated. The total flavonoids decreased the immobility time in the FST and TST, while increasing the sum of line crosses and number of rears and reduced the number of fecal boli produced in the OFT of the CMS rats. The total flavonoids lessened the serum corticosterone contents of the CMS rats, and increase the number of BrdU positive progenitor cells in the sub-granular zone of the dentate gyrus region in the hippocampus at a dose of $300 \mathrm{mg} / \mathrm{kg}$. Total flavonoids extract from cultivated Glycyrrhiza uralensis Fisch. produce antidepressant-like activity on CMS depression and the mechanism of action might be related to a neurogenesis protective effect.

Hibiscus (H.) esculentus L. (Okra) is widely distributed, and used as food in Africa, Asia, Southern European, and America. Ebrahimzadeh et al. [62] investigated the antidepressant-like activity of methanolic extracts of Okra seeds and leaves through the FST and TST, which include high amount of flavonoids and phenols. Seeds extracts remarkably decreased the immobility period at doses of 250,500 and $750 \mathrm{mg} / \mathrm{kg}$, respectively, and showed better antidepressant-like activity than a control $(P<0.001)$ in both FST and TST. Both extracts exhibited similar effect at a dose of $750 \mathrm{mg} / \mathrm{kg}$ as imipramine $(15 \mathrm{mg} / \mathrm{kg}$, $P>0.05)$ in the TST. No mortality was observed up to $2.5 \mathrm{~g} / \mathrm{kg}$ for leaves and $2 \mathrm{~g} / \mathrm{kg}$ for seeds.

Wu et al. [63] reported the immature fruit of Citrus aurantium L. (Zhi-Qiao, ZQ) have been used in China as a traditional medicine. The total of chemical constituents of a ZQ aqueous extract was identified by coupling ultra-performance liquid chromatography with time-of-flight mass spectrometry. The main components were 5 flavones, 13 flavanones, and 5 polymethoxylated flavonoids. The antidepressant-like effect of the ZQ aqueous extract was evaluated by the FST and TST and the immobility time of the mice were significantly shortened. MTT assays showed that both the ZQ aqueous extract and its major constituents had a neuro-protective effect on corticosterone-induced neurotoxicity in PC12 cells.

Ekeanyanwu et al. [64] reported that the antidepressant-like activities of the flavonoid-rich fraction from Monodora tenuifolia seed extract. They studied attenuation of behavioral alterations and oxidative damage in the rats that were stressed by the FST. The behavioral parameters were significantly attenuated $(P<0.05)$ in the group treated with the flavonoid-rich fraction at doses of 100 and $200 \mathrm{mg} / \mathrm{kg}$, and fluoxetine $(10 \mathrm{mg} / \mathrm{kg})$, compared with the model control group. The flavonoid-rich fraction and fluoxetine 
significantly improved $(P<0.05)$ the effects of the antioxidant enzymes superoxide (superoxide dismutase and catalase) dismutase and catalase, as well as improving other biochemical parameters (protein, reduced glutathione, and nitrite) in the brains of the stressed rats. These results suggest that the flavonoid-rich fraction of Monodora tenuifolia seed extract possess antidepressant-like activity that could be useful in the management of stress induced disease.

Torvanol A is isolated from Solanum torvum includes isoflavonoid compounds [65]. The antidepressant-like effect of torvanol A on behavioral despair were evaluated by the FST and TST in a CMS model. Torvanol A significantly decreased the immobility time at doses of 10 and $30 \mathrm{mg} / \mathrm{kg}$, respectively, compared to the control groups $(P<0.05)$. Combination of torvanol A with neurotransmitter antagonists haloperidol (50 $\mu \mathrm{g} / \mathrm{kg}$, i.p.), prazocin $(62.5 \mu \mathrm{g} / \mathrm{kg}$, i.p.), and PCPA (100 $\mathrm{mg} / \mathrm{kg}$, i.p.) produced the same effects in various behavioral parameters as the respective antagonists in the FST and TST. These findings indicate the involvement of noradrenergic, serotonergic, and dopaminergic mechanism for torvanol A.

Hydroalcoholic H. citrina extracts, mainly containing flavonoids hesperidin and rutin, were studied to evaluate their antidepressant-like activity by the TST and OFT and the possible action mechanism was investigated by analyzing brain monoamine neurotransmitters in mice. The extracts were evaluated by histopathology and toxicology to determine their safety for the oral administration. The $75 \%$ ethanol extract (HCE75) displayed the highest content of active flavonoids and significantly decreased the immobility times in the TST and exhibited the most antidepressant-like activity at a dose of $400 \mathrm{mg} / \mathrm{kg}$ (p.o.). This does also increased DA and 5-HT levels in the CNS. Lesions and mortality were not observed after oral administration of up to $5000 \mathrm{mg} / \mathrm{kg}$. The results indicate that the antidepressant-like activity of HCE75 might be related to the serotonergic and dopaminergic systems and that the active extract is toxicologically safe for oral administration [66].

\subsection{Flavonoid compounds}

Flavonoid compounds containing more than one pharmacyophore have been reported to possess antidepressant-like effect [67]. Apigenin (4', 5, 7-trihydroxyflavone) (Fig. 2) is a natural product widely found in fruits and vegetables that belongs to the flavone class. Nakazawa et al. [68] found that apigenin displayed antidepressant-like effect in the FST and studied the central 5-HT, NE, and DA effects in mice. apigenin significantly decreased the duration of immobility of mice in the FST at doses of 12.5 and 25 
$\mathrm{mg} / \mathrm{kg}$ (i.p.). However, the duration of immobility returned to that seen in the control group at a dose of 100 $\mathrm{mg} / \mathrm{kg}($ i.p). Monoamine turnover was measured in seven brain regions and the FST exposure induced a significant increases in DOPAC/DA in the hypothalamus and thalamus, and 3-methoxy-4-hydroxyphenylethyleneglycol (MHPG)/NE in the frontal cortex, hypothalamus, amygdala, and midbrain, while significantly reducing DOPAC/DA in the amygdale and striatum, and 5-HIAA/5-HT in the hypothalamus. Apigenin treatment at a dose of $25 \mathrm{mg} / \mathrm{kg}$ attenuated the FST-induced decrease of DA turnover in the amygdala and increased DA turnover in the hypothalamus. Dopamine D2 antagonist haloperidol (0.2 $\mathrm{mg} / \mathrm{kg}$, i.p.) blocked the apigenin-induced $(25 \mathrm{mg} / \mathrm{kg}$ ) decrease in immobility in the FST. These behavioral model and biochemical results suggest the antidepressant-like effect of apigenin might be mediated by dopaminergic mechanisms in the mouse brain [69]. Li et al. [70] also reported that pre-treatment with apigenin $(25$ and $50 \mathrm{mg} / \mathrm{kg}$, i.p.) once daily for 7 consecutive days prevented the abnormal behavior induced by lipopolysaccharide (LPS). Apigenin effectively attenuated LPS-induced production of pro-inflammatory cytokines IL-1 (interleukin-1 $\beta$ ) and TNF- $\alpha$ (tumor necrosis factor- $\alpha$ ) and significantly suppressed mRNA expression of both inducible nitric oxide synthase (iNOS) and cyclooxygenase-2 (COX-2). Apigenin effectively reversed the depressive-like behavior induced by TNF- $\alpha$ without altering locomotor activity at a dose of $50 \mathrm{mg} / \mathrm{kg}$ (i.p.). These results demonstrate that the anti-inflammatory properties of apigenin are partially responsible for the antidepressant-like effect in LPS-treated mice.

Luteolin (3', 4', 5, 7-tetrahydroxyflavone) is a flavonoid found in many plants (Fig. 2). Ishisaka et al. [71] reported that chronic oral administered of luteolin displayed antidepressant-like effect at a dose of 50 $\mathrm{mg} / \mathrm{kg} / \mathrm{day}$ in some behavioral tests (in the FST and TST). Luteolin also attenuated the expression of endoplasmic reticulum stress-related proteins in the hippocampus of depression model mice treated with corticosterone. Ishisaka et al. also investigated the effects of luteolin on endoplasmic reticulum stress-induced neuronal cell death, and found luteolin significantly suppressed tunicamycin-induced cell death in human neuroblastoma cells at doses of 1 and $10 \mu \mathrm{g} / \mathrm{mL}$. Luteolin significantly increased the expression of the $94 \mathrm{kDa}$ and $78 \mathrm{kDa}$ glucose-regulated proteins and decreased the cleavage activation of caspase-3. These results suggest that luteolin possesses antidepressant-like activity that may be partly attributed to the suppression of endoplasmic reticulum stress.

Zhen et al. [72] investigated the antidepressant-like effect of Fisetin (3, 3', 4', 7-tetrahydroxyflavone) (Fig. 2) by the FST and TST, and its possible mechanism using two behavioral models, ptosis caused by 
PCPA-induced depletion of 5-HT and reserpine-induced hypothermia in the serotonergic and noradrenergic systems. Fisetin dependently inhibited the immobility time at concentrations of 10 and $20 \mathrm{mg} / \mathrm{kg}$ (p.o.) in the FST and TST, without affecting locomotor activity. Fisetin was found to effectively antagonize reserpine-induced hypothermia at a dose of $20 \mathrm{mg} / \mathrm{kg}$, but not ptosis. Pre-treatment with PCPA abolished the anti-immobility effect of fisetin in the FST and TST. Neurochemical assays displayed that fisetin induced an increase in NE and 5-HT levels in the frontal hippocampus and cortex. MOA activity was inhibited in the mouse brain by $14.7 \%$ after treatment with fisetin, while MOA-B activity was not affected, suggesting that the antidepressant-like activity of fisetin includes the regulation of the central NE and 5-HT levels.

Quercetin (3, 3', 4', 5, 7-five hydroxyflavone) (Fig. 2), a bioflavonoid, was evaluated for antidepressant-like activity by the FST-induced behavioral despair test in 6-week-old streptozotocininduced diabetic mice at doses of 50 and $100 \mathrm{mg} / \mathrm{kg}$ (i.p.). Quercetin dose-dependently reduced the immobility period and the effect was comparable to imipramine $(15 \mathrm{mg} / \mathrm{kg}$, i.p. $)$ and fluoxetine $(5 \mathrm{mg} / \mathrm{kg}$, i.p.). Quercetin failed to induce any antidepressant-like effect in naive mice while imipramine and fluoxetine were effective in naive mice, indicating that quercetin is a potential therapy for depression associated with diabetes [73]. Demir et al. [74] also investigated the effects of quercetin at doses of 50 or $100 \mathrm{mg} / \mathrm{kg}$ (i.p.) for 21 days on depression-like behaviors and HPA axis induced by streptozotocin in diabetic rats. Quercetin treatment of $50 \mathrm{mg} / \mathrm{kg}$ significantly increased the total immobile time and was accompanied by a decrease in the immobility latency, suggesting a depressed state. A higher dose of quercetin $(100 \mathrm{mg} / \mathrm{kg})$ was ineffective in alleviating depression-like behavioral. The plasma concentrations of total- and free-corticosterone (CORT) and adrenocorticotropic hormone (ACTH) were not affected by either doses of quercetin. Park et al. [75] reported antidepressant-like activity of flavonoid compounds quercitrin and kaempferol isolated from Opuntia ficus-indica var. saboten using the TST and FST in a chronically restraint stress group of mice. The expression of hypothalamic POMC mRNA or plasma $\beta$-endorphin levels was increased by administration of quercitrin and kaempferol at a dose of $30 \mathrm{mg} / \mathrm{kg}$ (o.p.). Quercitrin and kaempferol significantly decreased the immobility time in the FST and TST and showed antidepressant-like effect.

Icariin (Fig. 3) is a flavonoid compound extracted from the traditional Chinese herb Herba Epimedii. Liu et al. [76] reported that icariin showed antidepressant-like activity in a social defeat mouse model, and 
investigated the effects of icariin on the depression-like behaviors in a CMS model of depression. Rats treated with chronic levels of icariin (20 or $40 \mathrm{mg} / \mathrm{kg}$ ) and exposed to CMS exhibited a significant increase in inflammatory mediators, oxidative-nitrosative stress markers (including interleukin-1 $\beta$ and tumor necrosis factor-alpha), inducible nitric oxide synthase mRNA expression in the hippocampus, and activation of the nuclear factor kappa B (NF-kB) signaling pathway. However, icariin negatively regulated the activation of the nod-like receptor-protein 3 inflammasome (NLRP3)/caspase-1/IL-1 $\beta$ axis in the hippocampus. These results suggested that icariin displayed the antidepressant-like effect are mediated by enhanced anti-inflammatory effect and the antioxidant status on the brain tissue via the inhibition of the NLRP3-inflammasome/caspase-1/IL-1 $\beta$ axis and NF- $\kappa B$ signaling activation.

Rutin (Fig. 3) is a glycosylated flavonol, an important class of flavonoids. Noldner and Schotz [77] reported that rutin exhibited the antidepressant-like activity of Hypericum perforatum extract. In addition, Machado et al. [78] also investigated the antidepressant potential of rutin isolated from the ethanolic extract of Schinus molle L. and found doses of 0.3-3 mg/kg (p.o.) shortened the immobility time in the FST-but not in the TST-without producing alteration in locomotor activity. Treatment of mice with $\alpha$-methyl-p-tyrosine (100 mg/kg, i.p.) and PCPA (100 mg/kg, i.p.) for 4 consecutive days prevented the anti-immobility activity of a $0.3 \mathrm{mg} / \mathrm{kg}$ (p.o.) dose of rutin in the TST. The results indicated that rutin exhibited the antidepressant-like activity by increasing the availability of 5-HT and NE in the synaptic cleft.

Vitexin (apigenin-8-C-glucoside) is a flavone C-glucoside (Fig. 3) present in nutraceuticals and foodstuffs that has been investigated for antidepressant-like effect using the TST and FST and its mechanisms. Vitexin significantly lessened the immobility time in the FST and TST of mice. The antidepressant-like activity of vitexin is dependent on an increase in catecholamine contents in the synaptic cleft, as well as on interaction with serotonergic $5-\mathrm{HT}_{1 \mathrm{~A}}$, noradrenergic $a_{2}$, and dopaminergic $\mathrm{D}_{1}, \mathrm{D}_{2}$, and $\mathrm{D}_{3}$ receptors. The level of 5-HT seemed unrelated to the observed antidepressant-like effect in the synapse [79].

Cassani et al. [80] evaluated the antidepressant-like activity of kaempferitrin isolated from the plant Justicia spicigera (Asteraceae) by the FST and TST of mice and explored the possible active mechanism and serotonergic system and involvement of the HPA axis. Nonspecific effects of kaempferitrin on general activity were evaluated by the OFT. Kaempferitrin shortened the immobility time at concentrations of 5, 10, 
and $20 \mathrm{mg} / \mathrm{kg}$ and produced a synergistic effect at a sub-effective dose of $1 \mathrm{mg} / \mathrm{kg}$ with desipramine $(3.12$ $\mathrm{mg} / \mathrm{kg})$ and fluoxetine $(10 \mathrm{mg} / \mathrm{kg})$, but not with imipramine $(6.25 \mathrm{mg} / \mathrm{kg})$. Pretreatment with $8 \mathrm{OH}-\mathrm{DPAT}$

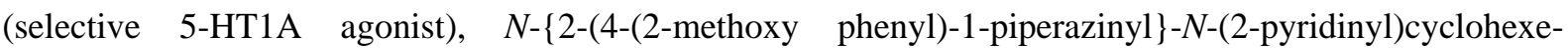
carboxamide (WAY-100635) (selective 5-HT1A receptor antagonist), and PCPA methyl ester blocked the anti-immobility effect induced by kaempferitrin. The results indicate that the possible mechanism of the antidepressant-like activity of kaempferitrin is related to the serotonergic system, principally $5-\mathrm{HT}_{1 \mathrm{~A}}$.

The possible cellular mechanisms of hyperoside (Fig. 3), a flavone C-glucoside isolated from Apocynum venetum leaves, was studied in corticosterone-induced neurotoxicity in vitro using PC12 cells as a model of depression. Cell viability was tested by 3-(4, 5-dimethylthiazol-2-yl)-2,5-diphenyltetrazolium bromide (MTT) assay. The release of lactic dehydrogenase (LDH) and intracellular $\mathrm{Ca}^{2+}$ concentration were determined by real-time RT-PCR of cAMP response element binding protein (CREB) transcript abundances a BDNF kit, respectively. Hyperoside protected PC12 cells from lesion induced by treatment with $10 \mu \mathrm{M}$ corticosterone for $48 \mathrm{~h}$ at doses of $2.5,5$ and $10 \mu \mathrm{g} / \mathrm{mL}$. Fura-2/AM analyses showed that hyperoside attenuated corticosterone-induced intracellular $\mathrm{Ca}^{2+}$ overloading at concentrations of $2.5,5$ and $10 \mu \mathrm{g} / \mathrm{mL}$ in PC12 cells. The transcript abundance of BDNF and CREB were elevated by hyperoside treatment in PC12 cells. The possible cellular mechanism of hyperoside for antidepressant-like effect is a cytoprotective action related to elevate expression of BDNF and CREB through the signal pathway AC-cAMP-CREB [81].

Structurally similar flavonoids apigenin, luteolin, fisetin, quercetin and kaempferol, which different in the number and location of hydroxy groups, were subjected to a SAR study for antidepressant effects. The position of hydroxy group(s) on the flavonoid A-ring influence antidepressant effects. Compounds with hydroxy group(s) at 2,4-positions or the 4-position on the flavonoid A-ring showed antidepressant activities. Flavone C-glucosides, both monosaccharides and disaccharides, exhibited better antidepressant activities, suggesting flavone derivatives possess antidepressant effects (as shown Fig. 3).

Seven flavonoids (apigenin-7-O-13-D-glucuronopyranoside, apigenin, luteolin, luteolin-7-O-13-Dglucopyranoside, (+)-dihydroquercetin (taxifolin), (+)-dihydrokaempferol (aromadendrin) and quercetin) were identified from Cayratia japonica through an activity-guided isolation of a methanol extract using a MAO inhibition assay. Apigenin, luteolin, and quercetin displayed potent inhibitory effects against MAO activity with $\mathrm{IC}_{50}$ values of $6.5,22.6$, and $31.6 \mu \mathrm{g} / \mathrm{mL}$, respectively (Fig. 4). The flavone glycosides, 
apigenin-7-O-13-D-glucuronopyranoside and luteolin-7-O-13-D-glucopyranoside, exhibited mild MAO inhibition ( $\mathrm{IC}_{50}: 81.7$ and $118.6 \mu \mathrm{g} / \mathrm{mL}$, respectively). The two flavanonol compounds, aromadendrin and taxifolin, also exhibited weak inhibition ( $\mathrm{IC}_{50}: 154.7$ and $153.1 \mu \mathrm{g} / \mathrm{mL}$, respectively). Quercetin possessed a more potent inhibitory effect on MAO-A than MAO-B [82]. The results suggested that the order of inhibitory potency against the MAO effect is shown as follows: flavone flavonol > flavone glycoside > flavanonol. It was observed that level of MAO inhibitory activity with increasing in the numbers of the hydroxyl groups or the presence of C-glycosides lowers antidepressant-like activity by increasing the hydrophilicity of these compounds, diminishing their permeability across the blood-brain barrier.

Liu et al. [83] synthesized a series of 7, 8-dihydroxyflavone derivatives and evaluated their agonism of tropomyosin-receptor-kinase B (TrkB) as a proxy for antidepressant-like activity (Fig. 5). Primary cortical cultures from E17 rat embryos were treated with $500 \mathrm{nM}$ of fourteen 7, 8-dihydroxyflavone compounds and the cell lysates analyzed by $p$-Akt ELISA. The 7, 8-dihydroxyflavone derivatives were administrated to mice at a dose of $1 \mathrm{mg} / \mathrm{kg}$ (o.p.) and TrkB phosphorylation and its downstream signaling cascades containing mitogen-activated protein kinase (MAPK) and Akt/protein Kinase B were analyzed by immunoblotting at various time points in mouse brain. The electron-donor $-\mathrm{N}\left(\mathrm{CH}_{3}\right)_{2}$ group of compound $\mathbf{8}$ activated TrkB and its downstream signaling cascades. The SAR study showed that 7, 8-dihydroxy groups are essential for the agonistic effect. Compound $\mathbf{8}$ activated TrkB and prevented KA-elicited neuronal cell death and suppressed KA-induced caspase-3 activation in a TrkB F616A mutant knock. Furthermore, the improvements after orally administrated of compound $\mathbf{8}$ at $5 \mathrm{mg} / \mathrm{kg}$ were not blocked by 1 NMPP1 in the FST. These data showed that compound $\mathbf{8}$ was an orally bioavailable TrkB agonists and showed potent antidepressant-like effect $[84,85]$.

\section{3 chalcone and flavanone compounds}

Isoliquiritin and liquiritin are chalcone and flavanone compounds, respectively, isolated from Glycyrrhiza uralensis (Fig. 6). The FST and TST were used to evaluate their antidepressant-like activity. Both liquiritin and isoliquiritin significantly decreased the immobility time in the FST and TST at doses of 10, 20 and $40 \mathrm{mg} / \mathrm{kg}$ for $30 \mathrm{~min}$ after treatment via gastric intubation and showed the antidepressant-like effect. The $20-\mathrm{mg} / \mathrm{kg}$ doses of liquiritin and isoliquiritin displayed the most significant activity in both tests. Both compounds significantly increased the levels of NE and 5-HT in the hypothalamus, hippocampus, and cortex. No significant changes in DA content were observed in the FST and TST. Liquiritin and 
isoliquiritin also significantly lowered the ratio of 5-HIAA/5-HT in the hypothalamus, hippocampus, and cortex, slowing down 5-HT metabolism compared with stressed mice treated with vehicle. Both compounds produced significant antidepressant-like effect, and a probable mechanism of action is an increase in 5-HT and NE in the CNS [86]. Zhao et al. also [87] explored the antidepressant-like activity and anti-oxidative effect of liquiritin using a CMS induced depression model in rats by evaluating plasma malondialdehyde levels and erythrocyte superoxide dismutase activity at doses of 10,20 , and $40 \mathrm{mg} / \mathrm{kg}$, administered via gastric intubation. The results showed liquiritin increased superoxide dismutase (SOD) effect, decreased production of malondialdehyde (MDA), and inhibited lipid peroxidation. These studies suggest that liquiritin has potential antidepressant-like effect, which may be related to defense of oxidative stress by liquiritin.

Isosakuranetin-5-O-rutinoside (Fig. 6) is a flavanone isolated from the leaves of Salvia elegans Vahl. González-Cortazar et al. [88] tested isosakuranetin-5-O-rutinoside for antidepressant-like activity in a FST at a dose of $15 \mathrm{mg} / \mathrm{kg}$ in mice. Treated mice displayed significantly decreased the immobility time in the FST $(P<0.05)$ and the compound has potent antidepressant-like activity.

Hesperidin (4'-methoxy-7-O-rutinosyl-3',5-dihydroxyflavanone) (Fig. 6), a naturally occurring flavanone glycoside, was investigated by Filho et al. [89] for involvement of the opioid system in the antidepressant-like effect seen in the FST. Hesperidin shortened the immobility time at doses of 0.1, 0.3 and $1 \mathrm{mg} / \mathrm{kg}$ (i.p.) in the FST. The effects of a $0.3 \mathrm{mg} / \mathrm{kg}$ dose of hesperidin were prevented by 2-(3,4-dichlorophenyl)- $N$-methyl- $N$-[(1S)-1-(3-isothiocyanatophenyl)-2-1-pyrrolidinyl)ethyl]acetamide (DIPPA, selective $\kappa$-opioid receptor antagonist), naltrindole (nonselective opioid receptor antagonist), naloxone methiodide (peripherally acting opioid receptor antagonist), and caffeine (selective $\delta$-opioid receptor antagonist) in the FST. The antidepressant-like effect of hesperidin might be related to the $\kappa$-opioid, $\mu$-opioid, $\delta$-opioid, and adenosinergic receptors. Souza et al. [90] also found the antidepressant-like effect of hesperidin at a dose of $0.3 \mathrm{mg} / \mathrm{kg}$ was prevented by WAY100635 (selective 5-HT(1A) receptor antagonist), PCPA methyl ester (inhibitor of serotonin synthesis), prazosin ( $\alpha(1)$-adrenoceptor antagonist), yohimbine, $\alpha$-methyl-p-tyrosine ( $\alpha(2)$-adrenoceptor antagonist), AMPT (inhibitor of tyrosine hydroxylase), propranolol (a, $\beta$-adrenoceptor antagonist), $\mathrm{SCH} 23390$ (dopamine $\mathrm{D}(1)$ receptor antagonist), sulpiride (dopamine $\mathrm{D}(2)$ receptor antagonist), and ketanserin (5-HT(2A/2C) receptor antagonist) in the TST. A possible mechanism is dependent on hesperidin interaction with the serotonergic 5- $\mathrm{HT}_{1 \mathrm{~A}}$ receptors [91]. 
Donato et al. [92] reported pretreatment with L-arginine (nitric oxide (NO) precursor), S-nitroso- $N$ acetyl-penicillamine (NO donor), sildenafil (phosphodiesterase inhibitor), methylene blue (inhibitor of NOS/soluble guanylate cyclase (sGC)) and ODQ (specific inhibitor sGS) significantly reversed the decrease in immobility time elicited by acute treatment of hesperidin in the TST. However, an additive antidepressant-like effect was observed with $N(\mathrm{G})$-nitro-L-arginine (inhibitor of nitric oxide synthase (NOS)) or 7-nitroindazole (neuronal NOS inhibitor) in the TST. Hesperidin caused a significant decrease in nitrate/nitrite (NOX) levels in the hippocampus of mice and also resulted in an increase in hippocampal BDNF levels. These results suggest that the antidepressant-like activity of hesperidin may be mediated by inhibition of the L-arginine-NO-cGMP pathway by increasing BDNF contents in the hippocampus. El-Marasy et al. [93] also reported that hesperidin reversed the STZ-induced increase in immobility duration in the FST, weakened hyperglycemia, exacerbatedinterleukin-6 (IL-6) decrease by glutathione (GSH), increased BDNF levels, and lowered MDA in the brain at doses of 25.0, 50.0, and $100.0 \mathrm{mg} / \mathrm{kg}$ (o.p.). Hesperidin also weakened STZ-induced neurochemical alterations (5-HT, NE and DA), which indicated the antidepressant-like activity might be mediate through anti-oxidant and anti-inflammatory activity and amelioration of hyperglycemia via revised the levels of monoamines and the enhancement of neurogenesis in the brain.

Lv et al. [94] investigated the antidepressant-like activity of astilbin by a CMS model of depression in mice (Fig. 6). Astilbin significantly decreased the immobility time in the FST and TST at doses of 10, 20 and $40 \mathrm{mg} / \mathrm{kg}$ (i.p.) and exhibited antidepressant-like behavior and sucrose preference test (SPT) without affecting locomotor activity. Astilbin increased DA and 5-HT levels in the frontal cortex of CMS mice. BDNF expression determined that astilbin treatment resolved CMS-induced inhibition of AKT phosphorylation and extracellular signal-regulated kinase (ERK) in the frontal cortex. The findings suggest that the antidepressant-like effect and mechanism of astilbin relate to up-regulation of monoaminergic neurotransmitters and activation of the BDNF signaling pathway.

Naringenin, a flavanone compound (Fig. 6), was investigated in behavioral models of depression and for anti-immobility effect when combined with pretreatment of NE and 5-HT synthesis inhibitors PCPA methyl ester and $\alpha$-methyl-p-tyrosine, respectively. Naringenin significantly decreased the immobility time after treatment at 10, 20 and $50 \mathrm{mg} / \mathrm{kg}$ in mouse FST and TST. Naringenin prevented the anti-immobility effect of $\alpha$-methyl-p-tyrosine and PCPA methyl ester at a dose of $20 \mathrm{mg} / \mathrm{kg}$ in the TST. Naringenin 
possesses potent antidepressant-like property via the central noradrenergic and serotonergic systems [95]. Yi et al. [96] also reported that naringenin reversed the prolonged first feeding latency in a novelty-suppressed feeding test (NSFT) and lowered SPT, without affecting home-cage feeding consumption. Naringenin also promoted BDNF expression in the hippocampus and frontal cortex in both non-stressed and CMS mice. The antidepressant-like effect of naringenin were abolished by inhibitor of BDNF receptor and tropomyosin-related kinase receptor B (TrkB) in SPT and NSFT and the antidepressant-like activity of naringenin might be mediated by the activation of BDNF signaling in the hippocampus.

Chalcone isoliquritin and flavanone maternal derivatives liquiritin, isosakuranetin-5-O-rutinoside, naringenin, astilbin, and hesperidin are isolated from plants and show antidepressant effect. Compounds with C-glucoside (except naringenin), exhibited better antidepressant activity, suggesting the flavanone and chalcone maternal derivatives possess the antidepressant-like effect.

Our research group started development of antidepressant agents based on flavonoid compounds in 2010. Seventeen chalcone compounds were synthesized using Claisene-Schmidt condensations and screened for their antidepressant-like activity using the FST and TST [97, 98] (Fig. 7). Twelve compounds significantly decreased the immobility time in the FST at doses of $10 \mathrm{mg} / \mathrm{kg}$ and showed good antidepressant-like activity. A compound with $-3,4-(\mathrm{OH})_{2}$ electron-donor groups compound $\mathbf{1 4}(p<0.01)$, and two compounds with electron-withdrawing groups $\mathbf{2 3}$ (3-bromo-2',4'-dihydroxychal cone) and 27 (2,6-dichloro $-2^{\prime}, 4^{\prime}$-dihydroxychalcone) were found to have the most potent antidepressant-like activity, and significantly lowered the duration of immobility when compared with the control $(p<0.001)$. Compounds $\mathbf{2 3}$ and $\mathbf{2 7}$ were chosen for behavioral tests. Compounds $\mathbf{2 3}$ and $\mathbf{2 7}$ significantly increased the cumulative number of head twitches ( $p<0.05$ vs. control) in the 5-HTP-induced mouse head-twitch test, and enhanced mouse lethality ( $p<0.05$ vs. control) induced by yohimbine. These results indicate that the serotonergic, but not the noradrenergic system, was involved in the antidepressant-like effect of compounds 23 and 27.

Next, we synthesized seventeen 2',4',6'-trihydroxychalcone derivatives and evaluated their antidepressant activity (Fig. 8). Nine of the compounds significantly shortened the immobility time in the FST at a dose of $10 \mathrm{mg} / \mathrm{kg}$, indicating antidepressant activity. A SAR of the antidepressant activity of the compounds showed that $\mathrm{Br}$ contributed more the antidepressant activity than $\mathrm{F}$ and $\mathrm{Cl}$ for halogen 
substituted compounds. The rank of activity for halogen substituted derivatives was $\mathrm{Br}>\mathrm{Cl}>\mathrm{F}$. Compound 35 (2-bromo-2', $4^{\prime}, 6^{\prime}$-trihydroxychalcone), which bears a $\mathrm{Br}$ atom at position 2 of the B-ring, showed the greatest antidepressant activity. Immobility time was lessened by $50.04 \%$ by a $10 \mathrm{mg} / \mathrm{kg}$ dose of $\mathbf{3 5}$, which is comparable to the effect of the same dose of fluoxetine (58.68\%). Compound $\mathbf{3 5}$ significantly shorten immobility duration in the FST and TST at doses of 10,20 , and $40 \mathrm{mg} / \mathrm{kg}$, in mice 30 min after treatment. The influence of electron-donor groups on antidepressant activity was compared. The contribution order for these groups was $3,4-(\mathrm{OH})_{2}>3-\mathrm{OCH}_{3}-4-\mathrm{OH}>3,4-\left(\mathrm{OCH}_{3}\right)_{2}>4-\mathrm{CH}_{3}>\mathrm{H}>$ 3,4-( $\left(\mathrm{CH}_{3}\right)_{2}>4-\mathrm{OCH}_{3}$. Compounds $\mathbf{4 3}$ and $\mathbf{4 4}$ significantly lessen the immobility time at $10 \mathrm{mg} / \mathrm{kg}$ when compared to the control $(p<0.01)$ and exhibited good antidepressant-like effect [99].

A series of 2'-hydroxy-4'-isoprenyloxychalcone derivatives were synthesized and evaluated for antidepressant-like activity using the FST and TST (Fig. 9). All compounds exhibited potential antidepressant-like activity via i.p. injection. Compounds bearing $-\mathrm{Br}$ (position-3) (53), $(-\mathrm{Cl})_{2}$ (positions-2,6) (56), and $-\mathrm{OCH}_{3}$ (position-3) (58) functionalities on the B-ring showed more antidepressant-like activity and promoted a significant decrease in the immobility time at a dose of $10 \mathrm{mg} / \mathrm{kg}$ in the FST (duration of immobility, s: control $=141.5 \pm 10.9 ; \mathbf{5 3}=36.7 \pm 8.5 ; \mathbf{5 6}=41.7 \pm 12.4 ; \mathbf{5 8}=40.5 \pm 9.2 ;$ fluoxetine $=62.5$ $\pm 9.3 \mathrm{~s}$ ) and TST (duration of immobility, s: control $=130.5 \pm 9.6 ; 53=42.3 \pm 7.9 ; 56=48.7 \pm 13.4 ; 58=$ $50.9 \pm 10.9$; fluoxetine $=40.4 \pm 8.7$ ). Inclusion of a halogen atom resulted in a variety of activity. $\mathrm{A} \mathrm{Br}$ atom contributed more for antidepressant-like activity than $\mathrm{F}$ and $\mathrm{Cl}$ atoms. Compounds $\mathbf{5 3}, \mathbf{5 6}$ and $\mathbf{5 8}$ were adequately absorbed in mice after oral administration at a dose of $30 \mathrm{mg} / \mathrm{kg}$. Compound $\mathbf{5 3}$ showed the most potential antidepressant-like activity, reducing the immobility time by $74.06 \%$ in the FST and $67.59 \%$ in the TST. Compound 58 (4-methoxyl-2'-hydroxy-4'-isoprenyloxychalcone) showed the most antidepressant-like activity for a compound containing an electron-donor group, lowering immobility time by $71.39 \%$ in the FST and $61.00 \%$ in the TST. Compound $\mathbf{5 3}$ increased head-twitches and raised mortality in mice in the 5-HT induced head-twitch and yohimbine-induced mortality tests. These effects may be related to the serotonergic and noradrenergic systems [100].

The antidepressant activity of a series of synthetic 2'-hydroxy-4',6'-diisoprenyloxychalcone derivatives were evaluated using the FST (Fig. 10). Five compounds, 64, 67 and 68-70, promoted a significant decrease in the immobility time in the FST at $10 \mathrm{mg} / \mathrm{kg}$ (duration of immobility, s: control = $116.7 \pm 12.3 ; \mathbf{6 4}=78.7 \pm 18.8 ; \mathbf{6 7}=72 \pm 11 ; \mathbf{6 8}=77.0 \pm 8.9 ; \mathbf{6 9}=79.3 \pm 16.8 ; \mathbf{7 0}=84.7 \pm 8.3 ;$ fluoxetine 
$=68.6 \pm 8.3)$. Compounds containing electron withdrawing 4-bromo (67) and 2,4-dichloro (55) and electron-donating 4-methoxy (57) substituents on the B-ring of chalcones exhibiting better antidepressant activity, and lowered the immobility time in the FST by $38.3 \%, 34.0 \%$, and $27.4 \%$, respectively. The decreases in immobility time in the TST were similarity to those seen in the FST. Compounds 67,68 , and 70 displayed significant antidepressant activity and promoted significant decreases in immobility time (duration of immobility, s: control $=130.5 \pm 9.6 ; \mathbf{6 7}=106.3 \pm 19.2 ; \mathbf{6 8}=88.0 \pm 16.6 ; \mathbf{7 0}=86.7 \pm 18.7$; fluoxetine $=75.6 \pm 8.3$ ). In addition, compounds 68 and $\mathbf{7 0}$ increased the rate of head twitching and increase the prevalence of mortality in the 5-HTP-induced head-twitch and yohimbine-induced mortality tests. The mechanism of the action of their antidepressant effect may be related to 5-HT and NE [101].

Two classic animal behavior despair tests, the FST and TST, were used to evaluate antidepressant-like activity of a new chalcone compound (chalcone-1203) in mice (Fig. 11). The immobility time in the FST was significantly diminished for three doses of chalcone-1203 (1,5 and $10 \mathrm{mg} / \mathrm{kg})$, a similar result to that of the positive control fluoxetine, indicating a significant antidepressant-like activity. The decreases in immobility time in the TST were similar to those seen in the FST. The $5 \mathrm{mg} / \mathrm{kg}$ dose showed the most significant activity in the FST (duration of immobility, s: control $=123.2 \pm 10.7 ; 1 \mathrm{mg} / \mathrm{kg}=91.5 \pm 19.9 ; 5$ $\mathrm{mg} / \mathrm{kg}=79.2 \pm 9.9 ; 10 \mathrm{mg} / \mathrm{kg}=92.5 \pm 12.8 ;$ fluoxetine $=82.3 \pm 8.0)\left(\mathrm{F}_{4.35}=14.55 ; p<0.001\right)$ and TST (duration of immobility, $\mathrm{s}$ : control $=130.5 \pm 9.6 ; 1 \mathrm{mg} / \mathrm{kg}=106.3 \pm 16.5 ; 5 \mathrm{mg} / \mathrm{kg}=78.2 \pm 9.6 ; 10 \mathrm{mg} / \mathrm{kg}$ $=86.7 \pm 18.7$; fluoxetine $=75.6 \pm 8.3)\left(\mathrm{F}_{4.35}=24.16 ; p<0.001\right)$. Chalcone-1203 was found to exhibit significant oral activity in the FST and to reduce ambulation in the OFT in mice not previously habituated to the arena, but had no effect on locomotor activity of mice that had previously habituated the OFT. Chalcone-1203 significantly increased the concentrations of 5-HT and NE in the hippocampus, hypothalamus and cortex and significantly lowered the ratio of 5-HIAA/5-HT in the hippocampus and cortex, slowing down 5-HT metabolism compared with stressed mice treated with vehicle. The mechanism of action of chalcone-1203 may be because of increased 5-HT and NE in the mouse hippocampus and cortex [102].

We have also synthesized fifteen 5, 7-dihydroxyflavanone compounds, flavonoids that are saturated at the 2, 3-positions of the C-ring, and evaluated their antidepressant activity in the FST (Fig. 12). Eight of the compounds significantly shortened the immobility time at $10 \mathrm{mg} / \mathrm{kg}$ compared to the control. The SAR of flavanone compounds with a halogen substituted on the B-ring revealed that a $\mathrm{Cl}$ atom contributed more to 
the antidepressant activity than $\mathrm{F}$ or $\mathrm{Br}$, and that the activity order was $\mathrm{Cl}>\mathrm{Br}>\mathrm{F}$. Compound $\mathbf{8 6}\left(2^{\prime}\right.$, 4'-dichloro-5, 7-dihydroxyflavanone) displayed the most antidepressant activity and lessened immobility time by $30.43 \%$. The contribution order of electron-donor groups on antidepressant activity is $3-\mathrm{OCH}_{3}-4-\mathrm{OH}>4-\mathrm{CH}_{3}>4-\mathrm{OCH}_{3}>-\mathrm{H}$. The antidepressant activity of compound 90 (4'-methoxy-5,7,3'trihydroxyflavanone) was significant and this compound significantly decreased the immobility time (duration of immobility, $\mathrm{s}$ : control $=141.0 \pm 14.2 ; \mathbf{9 0}=92.2 \pm 17.3$; fluoxetine $=70.3 \pm 5.8)$ by $34.61 \%(p$ $<0.001)[103]$.

We hypothesized that introducing a prenyl group substituent would increase the lipophilicity and permeability across the blood-brain barrier of our compounds, which would probably enhance their antidepressant-like activity. We introduced a prenyl group to the 7-position of dihydroflavanone compounds using Claisene-Schmidt condensations. A series of 7-prenyloxy-2,3-dihydroflavanone derivatives were synthesized and screened for their antidepressant-like activity in the FST and TST (Fig.13). Immobility times were significantly less after treatment with seven of the compounds $(\mathbf{9 3 - 9 5 , 9 7 , 9 8 , 1 0 0}$ and 101) in the FST, indicating antidepressant-like effect. Variations in activity were observed for the compounds containing electron-withdrawing $\mathrm{F}, \mathrm{Cl}$, and $\mathrm{Br}$ atoms on the $\mathrm{B}$-ring of the flavanone fragment. The order of activity was $4-\mathrm{Br}>2-\mathrm{Br}>3-\mathrm{Br}$ for bromides, $3-\mathrm{F}>4-\mathrm{F}>2-\mathrm{F}$ for fluorides, and $2,4-\mathrm{Cl}_{2}>$ 2- $\mathrm{Cl}>4-\mathrm{Cl}>3-\mathrm{Cl}>$ 6- $\mathrm{Cl}_{2}$ for chlorides. Compounds 100 (4'-bromo-7-prenyloxy-2,3-dihydroflavanone) and 101 (2', 4'-Dichloro-7-prenyloxy-2, 3-dihydroflavanone), containing a 4- $\mathrm{Br}$ and 2,4- $\mathrm{Cl}_{2}$ atoms, showed the most antidepressant-like effect, similar to the positive control drug fluoxetine. Two compounds (103 and 104) with electron-donor groups $\left(-\mathrm{CH}_{3}\right.$ and $\left.-\mathrm{OCH}_{3}\right)$ had no antidepressant-like activity in the FST. Compounds 100 and 101 significantly increased the concentrations of 5-HT and NE in the hippocampus, hypothalamus and cortex and significantly increased 5-HIAA in the hippocampus and cortex, shutting down 5-HT metabolism compared with stressed mice treated with vehicle. These results suggested that compounds 100 and 101 displayed potent antidepressant-like property that were mediated via neurochemical systems [104].

\section{Conclusion}

Flavonoid, chalcone, and flavanone compounds are excellent scaffolds for synthetic manipulations, and possess multiple biological activities and medicinal properties. The prevalence of flavonoid, chalcone, and flavanone derivatives in biologically active extracts has encouraged the synthesis of new compounds 
bearing these skeletons. These compounds have been largely targeted for their antidepressant-like effects. In this mini-review article we have emphasized the diverse antidepressant-like effects of total flavonoid extracts isolation from natural sources and synthetic flavonoids, chalcones, flavanones and their related analogues published in the last 15 years (2000-2015). We have also discussed the SAR and mechanism of action of these compounds.

\section{Acknowledgement}

This work was supported by the National Science Foundation of China (No. 30960458), and the Natural Science Foundation of Zhejiang Province of China (No. Y14C190001). We would like to express our gratitude to the past and present members of the group, as well as all of our collaborators for their contribution to our and studies over the years. 


\section{References}

[1] J.B. Harborne, C.A. Williams, Phytochemistry 55 (2000): 481.

[2] S. Karakaya, N.E.L. Sedef, Food Chem. 66 (1999) 289.

[3] T.G. Albuquerque, F. Santos, A. Sanches-Silva, M. Beatriz Oliveira, A.C. B ento, H.S. Costa, Food Chem. 193 (2016) 187.

[4] M.S. Nogueira, R.A. Furtado, J.K. Bastos, J. Agric. Food Chem. 63 (2015) 6939.

[5] M.Coleta, M.G. Campos, M. D. Cotrim, T.C M. de Lima, A.P.da Cunha, Behavioural Brain Res. 189 (2008) 75 .

[6] L.H. Mai, G.G. Chabot, P. Grellier, L. Quentin, V. Dumontet, C. Poulain, L.S. Espindola, S. Michel, H.T. Vo, B. Deguin, R. Grougnet, Eur. J. Med. Chem. 93 (2015) 93.

[7] E. Middleton Jr, C. Kandaswami, T.C.Theoharides, Pharmacol. Rev. 52 (2000) 673.

[8] D. Ahmed, M. Mehboob Khan, R. Saeed, Antioxidants 4 (2015) 394.

[9] J.B. Harborne, C.A. Williams, Phytochemistry 55 (2000) 481.

[10] G.Losi, G. Puia, G. Garzon, M.C. de Vuono, M.Baraldi, Eur. J. Pharmacol. 502 (2004) 41.

[11] M. Freitas, D. Ribeiro, S.M. Tomé, A.M. Silva, E. Fernandes, Eur. J. Med. Chem. 86 (2014) 153.

[12]C. Kontogiorgis, M. Mantzanidou, D. Hadjipavlou-Litina, Mini-Reviews in Med. Chem. 8 (2008) 1224.

[13] R. Raj, A. Saini, J. Gut, P.J. Rosenthal, V. Kumar, Eur. J. Med. Chem. 95(2015) 230.

[14] X. Jin, C.J. Zheng, M.X. Song, Y. Wu, L.P. Sun, Y.J. Li, L.J. Yu, H.R. Piao, Eur. J. Med. Chem. 56 (2012) 203.

[15] C. Meng, S. Zhang, Y.S. Deng, G.D. Wang, F.Y. Kong, Plant Physiol. Biochem. 96 (2015) 388.

[16] S. Emami, S. Shojapour, M.A. Faramarzi, N. Samadi, H. Irannejad, Eur. J. Med. Chem. 66 (2013) 480.

[17] P. Singh, A.Anand, V.Kumar, Eur. J. Med. Chem. 85 (2014) 758.

[18] M.A. Rahman, Chem. Sci. J. 2 (2011) CSJ-29.

[19] A.M. Katsori, D. Hadjipavlou-Litina, Expert Opin. Ther. Pat. 21 (2011) 1575.

[20] V.R. Yadav, S. Prasad, B. Sung, B.B. Aggarwal, Int. Immunopharmacol. 11(2011) 295.

[21] S. Nasir, A. Bukhari, M. Jasamai, I. Jantan, Mini Rev. Med. Chem. 12 (2012)1394. 
[22] S. Sinha1, B. Medhi, R. Sehga, J. Mod. Med. Chem. 1 (2013) 64.

[23] Z. Nowakowska, Eur. J. Med. Chem. 42 (2007) 125.

[24] M.J. Matos, S.Vazquez-Rodriguez, E. Uriarte, L. Santana, Expert Opin. Ther. Patents 25 (2014) 1.

[25] M.S. Gaffrey, J.L. Luby, D.M. Barch, Neurobiol. Disease 52 (2013) 38.

[26] S. Carde, S. Hatif, Soins Psychiatr. 37 (2016) 41.

[27] M.P. Kaster, M. Moretti, M.P. Cunha, A.L. Rodrigues, Eur. J. Pharmacol. 771 (2016) 236.

[28] World Health Organization (WHO). http://www.who.int/mediacentre/news/notes/2012/ mental_health _day_20121009/en/(accessed 9, October, 2012).

[29] A.D. Lopez, C.C. Murray, Nat. Med. 4 (1998) 1241.

[30] S. Ammendola, C. Kornreich, Rev. Med. Brux. 36 (2015) 421.

[31] M. Naughton, J.B. Mulrooney, B.E. Leonard, Human Psychopharmacol. 15 (2000) 397.

[32] L.F. Li, J. Yang, S.P. Ma, R. Qu, Eur. J. Pharmacol. 711 (2013) 42.

[33] R.J. Haier, M.S. Buchsbaum, E. DeMet, J. Wu, Neuropsychobiol. 20 (1988) 62.

[34] N. Barden, J.M. Reul, F. Holsboer, Trends Neurosci. 18 (1995) 6.

[35] L. Arborelius, M.J. Owens, P.M. Plotsky, C.B. Nemeroff, J. Endocrinol. 160 (1999) 1.

[36] R.S. Duman, G.R. Heninger, E.J. Nestler, Arch. Gen. Psychiatry 54 (1997) 597.

[37] F. Petty, M.H. Triyedi, M. Fulton, A.J. Rush, Biol. Psychiatry 38 (1995) 578.

[38] M.S.Thase, J. Clin. Psychiatry 64 (Suppl 13) (2003) 18.

[39] S.K. Bhattamisra, V. K. Khanna, A.K.Agrawal, P.N.Singh, S.K.Singh, J. Ethnopharmacology 117 (2008) 51.

[40] X.L. Meng, N. Zeng, Zhongguo Zhong Yao Za Zhi 21 (1996) 683.

[41] Z.Y. Shen, Y. Chen, J.H. Huang, Z.W.Hu, Chin. J. Immunol. 20 (2004) 59.

[42] C. Björkholm, L.M. Monteggia, Neuropharmacology 102 (2016) 72.

[43] K. Wędzony, A. Chocyk, M. Maćkowiak, Pharmacol. Rep. 65(2013) 1471.

[44] M.M. Saraceni, J.V. Venci, M.A. Gandhi, J. Pharm. Pract. 27 (2013) 389.

[45] Z. Lai, J. LiaoNing College Tradit. Chin. Med. 3 (2001) 266.

[46] V. Butterweck, G. Jürgenliemk, A. Nahrstedt, H. Winterhoff, Planta. Med. 66 (2000) 3.

[47] M. Wurglics, M. Schubert-Zsilavecz, Clin. Pharmacokinet. 45 (2006) 449.

[48] V. Butterweck, S. Nishibe, T. Sasaki, M. Uchida, Biol. Pharm. Bull. 24 (2001) 848. 
[49] G. Calapai, A. Crupi, F. Firenzuoli, G. Inferrera, F. Squadrito, A. Parisi, G. De Sarro, A. Caputi, Pharmacopsychiatry, 34 (2001) 45.

[50] D. Dhingra, A. Sharm, Prog. Neuro-Psychopharmacol. Biol. Psychiatry 30 (2006) 449.

[51] Y.Z. Zhang, Y.F. Li, N.J. Yu, L. Yuan, Y.M. Zhao, W.B. Xiao, et al. Chin. Med. J. (Engl) 120 (2007) 1792.

[52] Y.Z. Zhang, N.J. Yu, L. Yuan, L. An, Y.M. Zhao, W.B. Xiao, et al. Chin. J. Pharmacol. Toxicol. 22 (2008) 1.

[53] L. An, Y.Z. Zhang, N.J. Yu, X.M. Liu, N. Zhao, L. Yuan, et al. Pharmacol. Biochem. Behav. 89 (2008) 572.

[54] L. An, Y.Z. Zhang, N.J. Yu, X.M. Liu, N. Zhao, L. Yuan, H.X. Chen, Y.F. Li, Prog. Neuro-Psychopharmacol. Biological Psychiatry 32 (2008) 1484.

[55] M. Messaoudi, J.F. Bisson, A. Nejdi, P. Rozan, H. Javelot, Nutr. Neurosci. 11 (2008) 269.

[56] M. Herrera-Ruiz, A. Zamilpa, M. González-Cortazar, R. Reyes-Chilpa, E. León, M.P. García, J. Tortoriello, M. Huerta-Reyes, Phytomedicine 18 (2011) 1255.

[57] P.B. Shewale, R.A. Patil, Y. A. Hiray, Indian J. Pharmacol. 44 (2012) 454.

[58] M.Z. Zhang, S.L. Wu, D.F. Shi, C.M. Liu, Chin. Tradit. Herbal Drugs, 43 (2012) 2468.

[59] M.Z. Zhang, C.M. Liu, W. Hu, D.F. Shi, Y.C. Zhang, G.M.Wu, Li Shi Zhen Med. Materia Med. Res. $22(2011) 2319$.

[60] M. Zheng, Y. Fan, D. Shi, C. Liu, J. Ethnopharmacol. 147 (2013) 108.

[61] Z.Z. Fan , W.H. Zhao, J. Guo , R.F. Cheng, J.Y. Zhao, W.D. Yang, Y.H. Wang , W. Li , X. D. Peng, Yao Xue Xue Bao. 47 (2012) 1612.

[62] M.A. Ebrahimzadeh, S. M. Nabavi, S. F. Nabavi, Eur. Rev. Med. Pharmacol. Sci. 17 (2013) 2609.

[63] M. Wu, H. Zhang, C. Zhou, H. Jia, Z. Ma, Z. Zou, Molecules. 20 (2015) 6925.

[64] R.C. Ekeanyanwu, O.U. Njoku, Chin. J. Nat. Med. 13 (2015) 183.

[65] M. Mohan, D. Attarde, R. Momin, S. Kasture, Nat. Prod. Res. 27 (2013) 2140.

[66] B. Du, X. Tang, F. Liu, C. Zhang, G. Zhao, F. Ren, X. Leng, BMC Complement Altern Med. 14 (2014) 326.

[67] R. Bahramsoltani, M.H. Farzaei, M.S. Farahani, R. Rahimi, Rev. Neurosci. 26 (2015) 699.

[68] T. Nakazawa, T. Yasuda, J. Ueda, K. Ohsawa, Biol. Pharm. Bull. 26 (2003) 474. 
[69] L.T. Yi, J.M. Li, Y.C. Li, Y. Pan, Q. Xu, L.D. Kong, Life Sci.82 (2008) 741.

[70] R.P. Li, D. Zhao, R. Qu, Q. Fu, S.P. Ma, Neurosci. Lett. 594 (2015) 17.

[71] M. Ishisaka, K. Kakefuda, M. Yamauchi, K. Tsuruma, M. Shimazawa, A. Tsuruta, H. Hara, Biol. Pharm. Bull. 34 (2011) 1481.

[72] L. Zhen, J. Zhu , X. Zhao, W. Huang, Y. An, S. Li, X. Du, M. Lin, Q. Wang, Y. Xu, J. Pan, Behav. Brain Res. 228(2012) 359.

[73] Anjaneyulu M, Chopra K, Kaur I. J. Med. Food. 6 (2003) 391.

[74]E.A. Demir, H.S. Gergerlioglu, M. Oz, Acta. Neuropsychiatr. 28 (2016) 23.

[75] S.H. Park, Y.B. Sim, P.L. Han, J.K. Lee, H.W. Suh, Exp. Neurobiol. 19 (2010) 30.

[76] B. Liu, C. Xu , X. Wu, F. Liu, Y. Du, J. Sun, J. Tao , J. Dong, Neurosci. 294 (2015) 193.

[77] M. Noldner, K. Schotz, Planta. Med. 68 (2002) 577.

[78] G. Machado Daniele, E.B. Bettio Luis, P. Cunha Mauricio, R.S. Santos Adair, G. Pizzolatti Moacir, M.C. Brighente Inês, S. Rodrigues Ana Lúcia, Eur. J. Pharmacolo. 587 (2008) 163.

[79] Ö.D. Can, Ü.D. Özkay, Ü. Í. Ücel. Eur. J. Pharmacolo. 699 (2013) 250.

[80] J. Cassani, A.M. Dorantes-Barrón, L.M. Novales, G.A. Real, R. Estrada-Reyes, Molecules 19 (2014) 21442

[81] M. Zheng, C. Liu, F. Pan, D. Shi, Y. Zhang, Phytomedicine 19 (2012) 145.

[82] X.H. Han, S.S. Hong, J.S. Hwang, M.K. Lee, B.Y. Hwang, J.S. Ro, Arch. Pharm. Res. 30 (2007) 13.

[83] X. Liu, C.B. Chan, S.W. Jang, S. Pradoldej, J. Huang, K. He, L.H. Phun, S. France, G. Xiao, Y. Jia, H.R. Luo, K. Ye, J. Med. Chem. 53 (2010) 8274.

[84] X. Liu, C.B. Chan, Q. Qi, G. Xiao, H.R. Luo, X. He, K. Ye, J. Med. Chem. 55(2012) 8524.

[85] X. Liu, Q. Qi, G. Xiao, J. Li , H.R. Luo, K. Ye, Pharmacology 91(2013) 185.

[86] W.X. Wang, X.Y. Hu, Z.Y. Zhao, P. Liu, Y.C. Hu, J.P. Zhou, D.F.Zhou, Z.B.Wang, D.Guo, H.Z. Guo, Prog. Neuro-Psychopharmacol. Biol. Psychiatry 32 (2008) 1179.

[87] Z. Zhao, W. Wang, H. Guo, D. Zhou, Behav. Brain Res. 194 (2008) 108.

[88] M. González-Cortazar, A.M. Maldonado-Abarca, E. Jiménez-Ferrer,S. Marquina, E. Ventura-Zapata, A. Zamilpa, J. Tortoriello, M. Herrera-Ruiz. Molecules 18 (2013) 13260.

[89] C.B. Filho, L. Del Fabbro, M.G.. de Gomes, A.T. Goes, L.C. Souza, S.P. Boeira, C.R. Jesse, Eur. J. Pharmacol. 698 (2013) 286. 
[90] L.C. Souza, M.G. de Gomes, A.T. Goes, L. Del Fabbro, C.B. Filho, S.P. Boeira, C.R. Jesse, Prog. Neuropsychopharmacol. Biol. Psychiatry 40 (2013) 103.

[91] A. Roohbakhsh, H. Parhiz, F. Soltani, R. Rezaee, M. Iranshahi, Life Sci. 113 (2014) 1.

[92] F. Donato, M.G. de Gomes, A.T. Goes, C.B. Filho, L. Del Fabbro, M.S. Antunes, L.C.Souza, S.P. 95Boeira, C.R. Jesse, Brain Res. Bull. 104 (2014) 19.

[93] S.A. El-Marasy, H.M. Abdallah, S.M. El-Shenawy, A.S. El-Khatib, O.A. El-Shabrawy, S.A. Kenawy, Can. J. Physiol. Pharmacol. 92 (2014) 945.

[94] Q.Q. Lv, W.J. Wu, X.L. Guo, R.L. Liu, Y.P. Yang, D.S. Zhou, J.X. Zhang, J.Y. Liu, Biol. Pharm. Bull. 37 (2014) 987.

[95] L.T. Yi, C.F. Li, X. Zhan, C.C. Cui, F. Xiao, L.P. Zhou, Y. Xie, Prog. Neuropsychopharmacol. Biol. Psychiatry 34 (2010) 1223.

[96] L.T. Yi, B.B. Liu, J. Li, L. Luo, Q. Liu, D.Geng, Y. Tang, Y. Xia, D. Wu, Prog. Neuropsychopharmacol. Biol. Psychiatry 48 (2014) 135.

[97] D.H. Zhao, Y.Z. Zhang, Z.H. Zheng, Li Shi Zhen Med. Materia. Med. Res. 21 (2010) 1115.

[98] L.P. Guan, D.H. Zhao, Y. Chang, Z.S. Wen, L.M. Tang, F.F. Huang, Drug Res. 63 (2013) 46.

[99] X. Sui, Y.C. Quan, Y. Chang, R.P. Zhang, Y.F. Xu, L.P. Guan. Med. Chem. Res. 21 (2012) 1290.

[100] C. Xie, Z. Peng, S.L. Zhao, C.Y. Pan, L.P. Guan, X.Y. Sun, Med. Chem. 10 (2014) 789.

[101] L.P. Guan, D.H. Zhao, Y. Chang, Y. Sun, X.L. Ding, J.F. Jiang, Med. Chem. Res. 22 (2013) 5218.

[102] L.P. Guan, L.M. Tang, C.Y. Pan, S.L. Zhao, S.H. Wang. Neurochem. Res. 39 (2014) 313.

[103] D.H. Zhao, X. Sui, Y.L. Qu, L.Y. Yang, X. Wang, L.P. Guan, Asian J. Chem. 23 (2011) 1129.

[104] X.H. Zhen, Y.C. Quan, Z. Peng, Y. Han, Z.J. Zheng, L.P. Guan. Chem. Biol. Drug Des. 2015 Dec 26. doi: 10.1111/cbdd.12717. [Epub ahead of print]PMID: 26705885. 


\section{Captions for Figures}

Figure 1. Structures of flavonoids, chalcones and flavanones.

Figure 2. The structures of apigenin, luteolin, fisetin, quercetin and kaempferol.

Figure 3. icariin, rutin, vitexin, kaempferitrin and hyperoside compounds

Figure 4. The structures of compounds 1-7.

Figure 5. The structures of 7,8-dihydroxyflavone derivatives and the most active $\mathbf{8}$.

Figure 6. The structures of isoliquritin and liquiritin, isosakuranetin-5-O-rutinoside, naringenin, astilbin, and hesperidin.

Figure 7. Chalcone compounds 11-27 and the most active 14, 23 and 27.

Figure 8. Structure of chalcone compounds $28-\mathbf{4 4}$.

Figure 9. Structure of chalcone compounds 45-63.

Figure 10. Structure of chalcone compounds 64-75.

Figure 11. Structure of chalcone-1203.

Figure 12. Structure of dihydroxyflavanone compounds 76-90.

Figure 13. Structure of dihydroxyflavanone compounds 91-104. 
<smiles>O=c1cc(-c2ccccc2)oc2ccccc12</smiles>

flavonoids<smiles>O=C(/C=C/c1ccccc1)c1ccccc1</smiles>

chalcones<smiles>O=C1CC(c2ccccc2)Oc2ccccc21</smiles>

flavanones 
<smiles>O=c1cc(-c2ccc(O)cc2)oc2cc(O)cc(O)c12</smiles><smiles>O=c1cc(-c2ccc(O)c(O)c2)oc2cc(O)cc(O)c12</smiles><smiles>O=c1c(O)c(-c2ccc(O)c(O)c2)oc2cc(O)ccc12</smiles><smiles>O=c1c(O)c(-c2ccc(O)c(O)c2)oc2cc(O)cc(O)c12</smiles><smiles>COc1cccc(-c2cc(=O)c3c(O)cc(O)cc3o2)c1</smiles>

Fig. 2. The structures of apigenin, luteolin, fisetin, quercetin and kaempferol. 

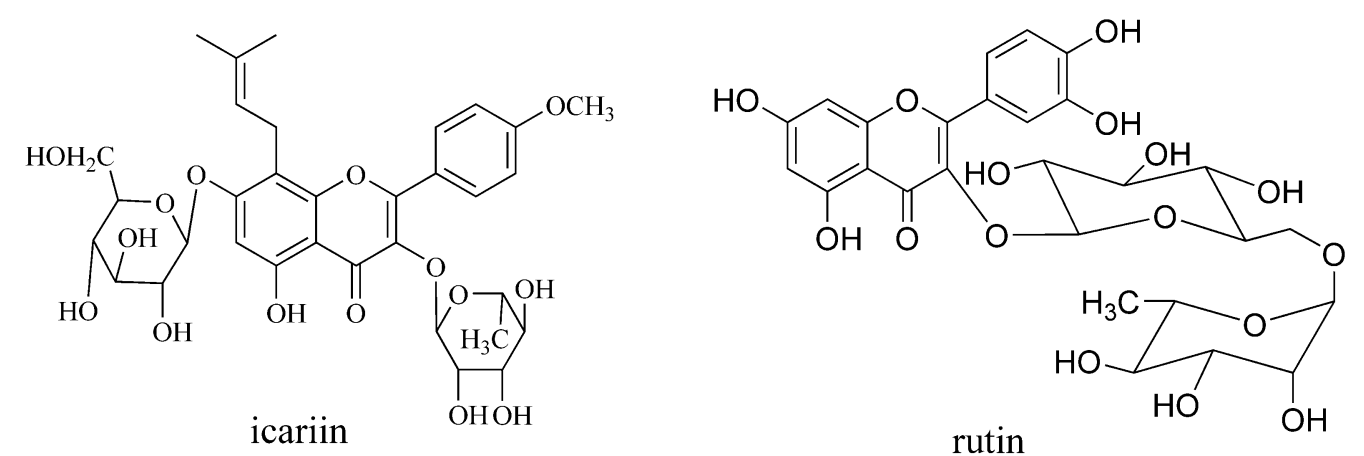<smiles>O=c1cc(-c2ccc(O)cc2)oc2c([C@@H]3OC(CO)[C@@H](O)[C@H](O)[C@H]3O)c(O)cc(O)c12</smiles>

vitexin<smiles>C[C@@H]1O[C@H](Oc2cc(O)c3c(=O)c(O[C@H]4C[C@H](C)[C@@H](O)[C@H](O)[C@H]4O)c(-c4ccc(O)cc4)oc3c2)[C@H](O)[C@@H](O)[C@@H]1O</smiles>

kaempferitrin<smiles>O=c1c(O[C@@H]2O[C@H](CO)[C@@H](O)[C@H](O)[C@H]2O)c(-c2ccc(O)c(O)c2)oc2cc(O)cc(O)c12</smiles>

hyperoside 
<smiles>[R]c1cc(O)c2c(=O)cc(-c3ccc(O)c([R2])c3)oc2c1</smiles>

$\mathbf{1}: \mathrm{R}_{1}=$ glucuronopyranoside, $\mathrm{R}_{2}=\mathrm{H}$

$2: \mathrm{R}_{1}=\mathrm{OH}, \mathrm{R}_{2}=\mathrm{H}$

3: $\mathrm{R}_{1}=\mathrm{OH}, \mathrm{R}_{2}=\mathrm{OH}$

$4: \mathrm{R}_{1}=$ glucopyranose, $\mathrm{R}_{2}=\mathrm{OH}$

Fig. 4. The structures of compounds 1-7.<smiles>[R7]c1cc([C@H]2Oc3cc(O)cc(O)c3C(=O)[C@@H]2O)ccc1O</smiles>

$5: \mathrm{R}_{1}=\mathrm{OH}$

$6: \mathrm{R}_{1}=\mathrm{H}$<smiles>O=c1c(O)c(-c2ccc(O)c(O)c2)oc2cc(O)cc(O)c12</smiles>

7 
<smiles>[R][X]1C=C(c2cc(=O)c3ccc(O)c(O)c3o2)C=[X]C1[X]</smiles>

8: $\mathrm{R}=\mathrm{NMe}_{2}, \mathrm{X}=\mathrm{CH}$

9: $\mathrm{R}=\mathrm{F}, \mathrm{X}=\mathrm{CH}$

10: $R=H, X=N$<smiles>CN(C)c1ccc(-c2cc(=O)c3ccc(O)c(O)c3o2)cc1</smiles>

8

Fig. 5. The structures of 7,8-dihydroxyflavone derivatives and the most active $\mathbf{8}$. 

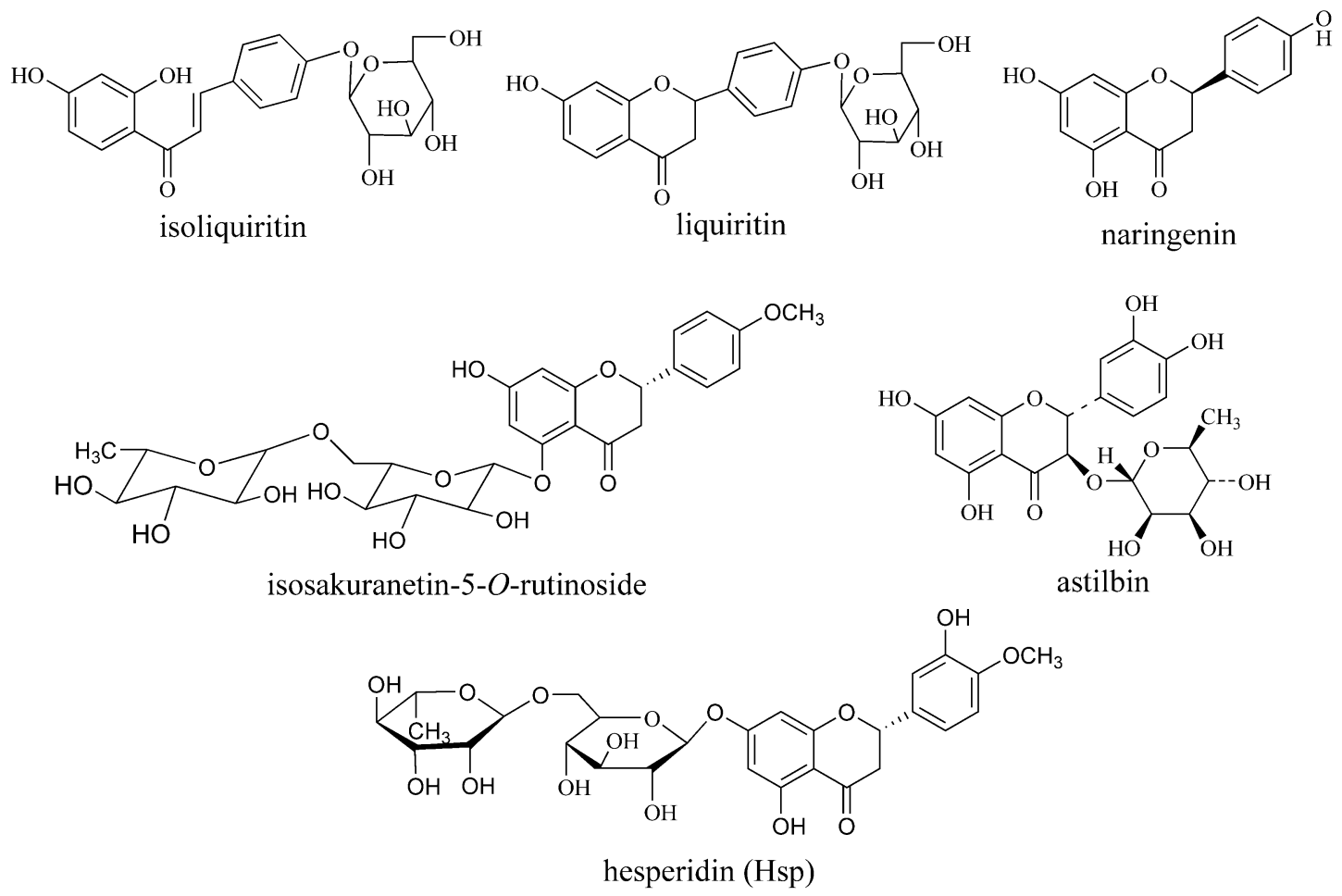

Fig. 6. The structures of isoliquritin and liquiritin, isosakuranetin-5-O-rutinoside, naringenin, astilbin, and hesperidin. 
<smiles>O=C(/C=C/c1ccc(O)cc1O)c1ccc(O)cc1O</smiles>

$\mathrm{R}:$

$11=\mathrm{H}, 12=4-\mathrm{OH}, 13=4-\mathrm{CH}_{3}, 14=3,4-(\mathrm{OH})_{2}, 15=3-\mathrm{OCH}_{3}-4-\mathrm{OH}, 16=4-\mathrm{N}_{(}\left(\mathrm{CH}_{3}\right)_{2}, 17=4-\mathrm{Cl}, 18=2-\mathrm{F}$, $19=2-\mathrm{Cl}, 20=2-\mathrm{Br}, 21=3-\mathrm{F}, 22=3-\mathrm{Cl}, 23=3-\mathrm{Br}, 24=4-\mathrm{F}, 25=4-\mathrm{Br}, 26=2,4-\mathrm{Cl}_{2}, 27=2,6-\mathrm{Cl}_{2}$

Fig. 7. Chalcone compounds 11-27 and the most active 14, 23 and 27. 


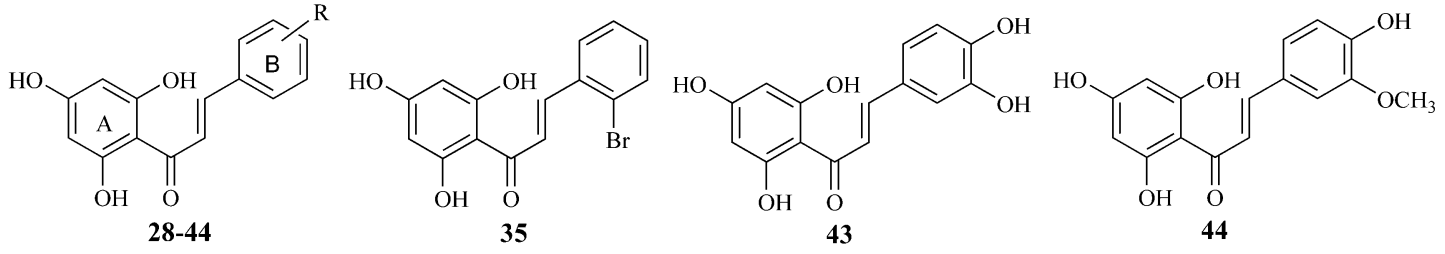

$\mathrm{R}:$

$28=\mathrm{H}, 29=2-\mathrm{F}, 30=3-\mathrm{F}, 31=4-\mathrm{F}, 32=2-\mathrm{Cl}, 33=3-\mathrm{Cl}, 34=4-\mathrm{Cl}, 35=2-\mathrm{Br}, 36=3-\mathrm{Br}, 37=4-\mathrm{Br}, 38=2,4-\mathrm{Cl}_{2}$,

$39=4-\mathrm{CH}_{3}, 40=3,4-\left(\mathrm{CH}_{3}\right)_{2}, 41=4-\mathrm{OCH}_{3}, 42=3,4-\left(\mathrm{OCH}_{3}\right)_{2}, 43=3,4-(\mathrm{OH})_{2}, 44=3-\mathrm{OCH}_{3}-4-\mathrm{OH}$

Fig. 8. Structure of chalcone compounds $28-44$. 
<smiles>[Y][R]1cccc(/C=C/C(=O)c2ccc(OCC=C(C)C)cc2O)c1</smiles>

$\mathrm{R}:$

$45=\mathrm{H}, 46=2-\mathrm{F}, 47=3-\mathrm{F}, 48=4-\mathrm{F}, 49=2-\mathrm{Cl}, 50=3-\mathrm{Cl}, 51=4-\mathrm{Cl}, 52=2-\mathrm{Br}, 53=3-\mathrm{Br}, 54=4-\mathrm{Br}$

$55=2,4-\mathrm{Cl}_{2}, 56=2,6-\mathrm{Cl}_{2}, 57=4-\mathrm{CH}_{3}, 58=4-\mathrm{OCH}_{3}, 59=4-\mathrm{N}\left(\mathrm{CH}_{3}\right)_{2}, 60=3-\mathrm{OCH}_{3}-4-\mathrm{OH}, 61=4-\mathrm{NO}_{2}$ $62=4-\mathrm{CH}_{2} \mathrm{CH}=\mathrm{C}\left(\mathrm{CH}_{3}\right)_{2}, 63=3,4-\left[\mathrm{CH}_{2} \mathrm{CH}=\mathrm{C}\left(\mathrm{CH}_{3}\right)_{2}\right]_{2}$

Fig. 9. Structure of chalcone compounds 45-63. 


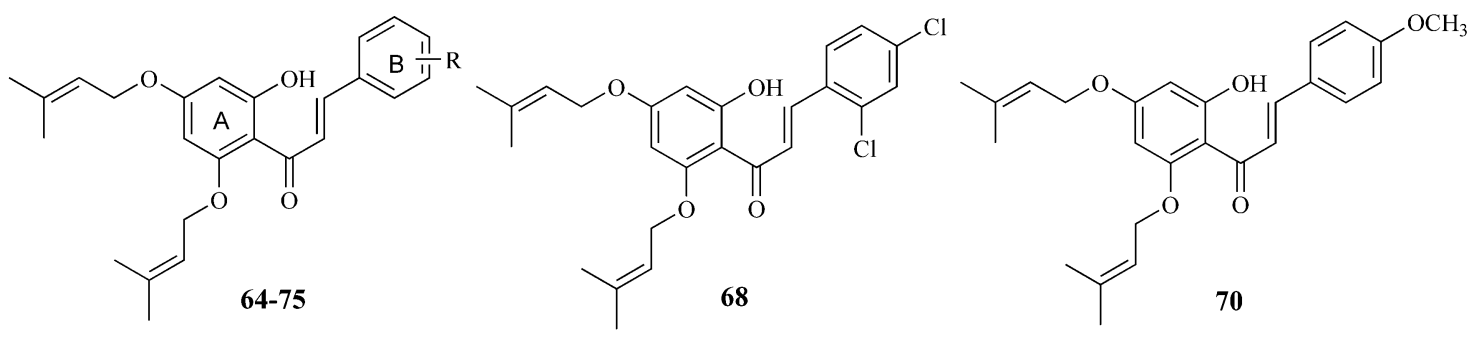

$\mathrm{R}$ :

$64=\mathrm{H}, 65=4-\mathrm{F}, 66=4-\mathrm{Cl}, 67=4-\mathrm{Br}, 68=2,4-\mathrm{Cl}_{2}, 69=4-\mathrm{CH}_{3}, 70=4-\mathrm{OCH}_{3}, 71=4-\mathrm{N}\left(\mathrm{CH}_{3}\right)_{2}$, $72=3-\mathrm{OCH}_{3}-4-\mathrm{OH}, 73=4-\mathrm{NO}_{2}, 74=4-\mathrm{OCH}_{2} \mathrm{CH}=\mathrm{C}\left(\mathrm{CH}_{3}\right)_{2}, 75=3,4-\left[\mathrm{CH}_{2} \mathrm{CH}=\mathrm{C}\left(\mathrm{CH}_{3}\right)\right]_{2}$

Fig. 10. Structure of chalcone compounds 64-75. 


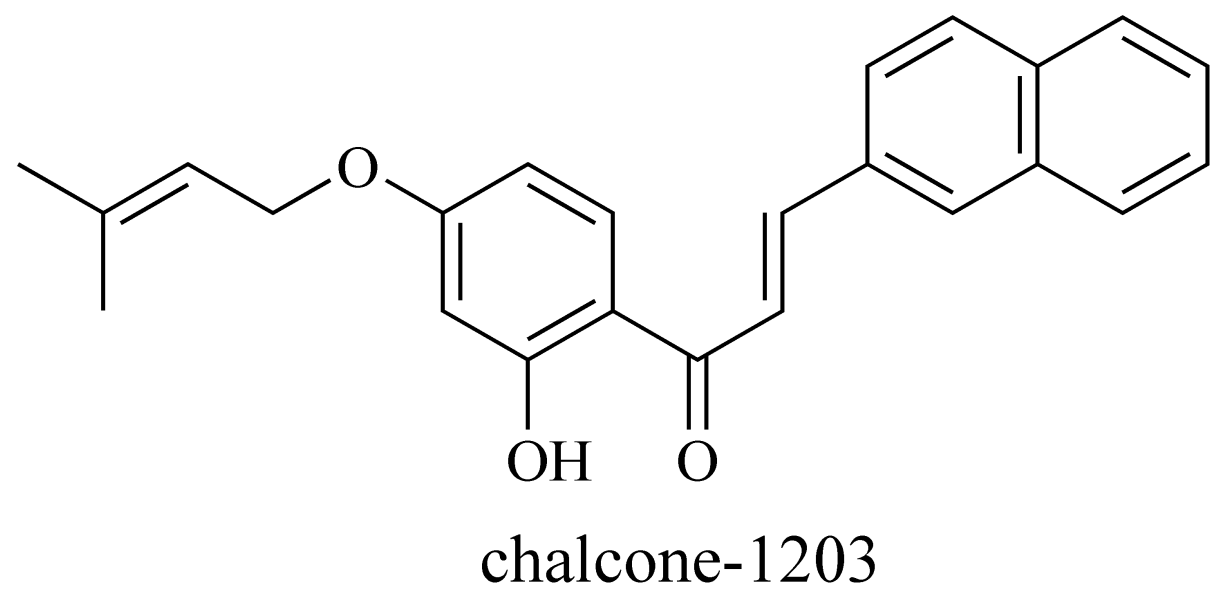

Fig. 11. Structure of chalcone-1203. 


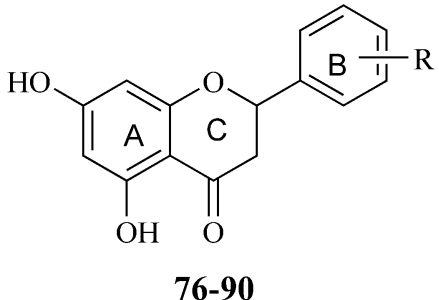

76-90<smiles>O=C1CC(c2ccc(Cl)cc2Cl)Oc2cc(O)ccc21</smiles>

86<smiles>COc1cc(C2CC(=O)c3ccc(O)cc3O2)ccc1O</smiles>

90

$\mathrm{R}$ :

$76=2-\mathrm{F}, 77=3-\mathrm{F}, 78=4-\mathrm{F}, 79=2-\mathrm{Cl}, 80=3-\mathrm{Cl}, 81=4-\mathrm{Cl}, 82=2-\mathrm{Br}, 83=3-\mathrm{Br}, 84=4-\mathrm{Br}$ $85=3-\mathrm{CF}_{3}, 86=2,4-\mathrm{Cl}_{2}, 87=\mathrm{H}, 88=4-\mathrm{CH}_{3}, 89=4-\mathrm{OCH}_{3}, 90=3-\mathrm{OCH}_{3}-4-\mathrm{OH}$

Fig. 12. Structure of dihydroxyflavanone compounds 76-90. 


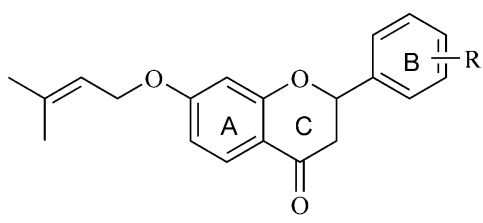

91-104

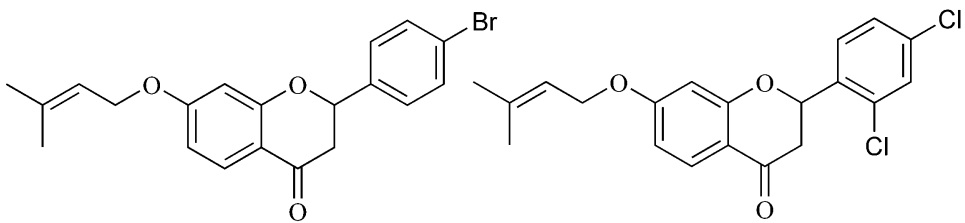

100
101

$\mathrm{R}$ :

$91=\mathrm{H}, 92=2-\mathrm{F}, 93=3-\mathrm{F}, 94=4-\mathrm{F}, 95=2-\mathrm{Cl}, 96=3-\mathrm{Cl}, 97=4-\mathrm{Cl}, 98=2-\mathrm{Br}, 99=3-\mathrm{Br}, 100=4-\mathrm{Br}$ ,101 $=2,4-\mathrm{Cl}_{2}, 102=2,6-\mathrm{Cl}_{2}, 103=4-\mathrm{CH}_{3}, 104=4-\mathrm{OCH}_{3}$

Fig. 13. Structure of dihydroxyflavanone compounds 91-104. 
Graphical Abstract

Antidepressant-like effects and mechanisms of flavonoids and related analogues

Li-Ping Guan, Bing-Yu Liu<smiles>O=c1cc(-c2ccccc2)oc2ccccc12</smiles>

flavonoids<smiles>O=C(/C=C/c1ccccc1)c1ccccc1</smiles>

chalcones<smiles>O=C1CC(c2ccccc2)Oc2ccccc21</smiles>

flavanones

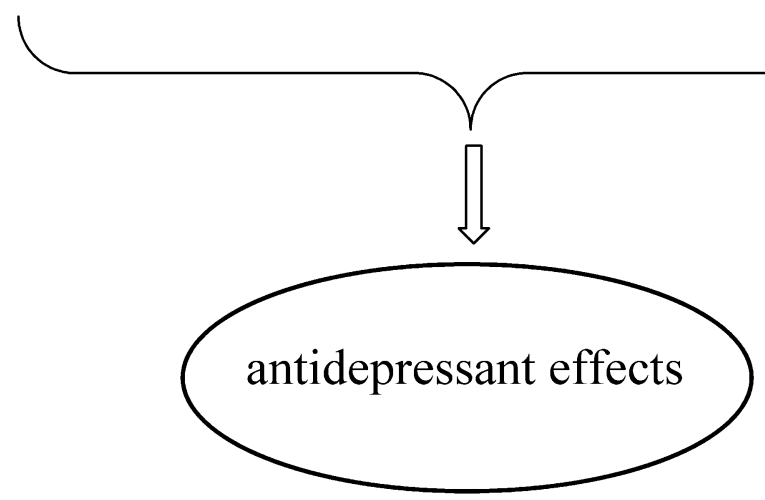

